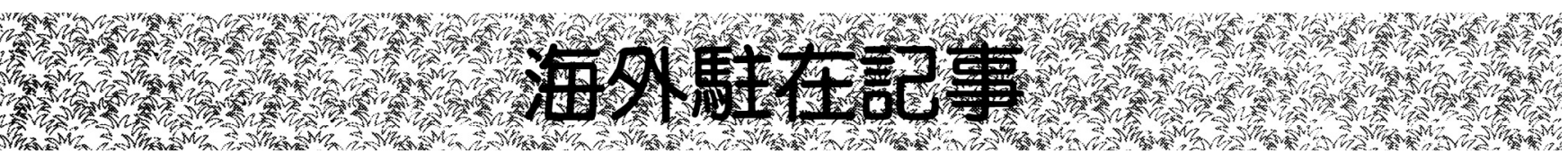

\title{
オーストリア共和国 ウィーン滞在記
}

\section{1. はじめに}

オーストリア共和国ウィーンに赴任したのは 2008 年 10 月で，既に半年以上をウィーンで生活している。組織・人 事コンサルティング会社マーサーが発表している『世界生 活環境調査』によると, ウィーンは毎年上位にランクイン している（2009 年は 1 位）。生活インフラはきちんと整っ ており, 緑地（所謂ウィーンの森）も多く, 非常に快適で ある。

筆者は国際応用システム分析研究所 (International Institute for Applied Systems Analysis）に弊社より派遣さ れ，気候変動対策とエネルギーシステムに関する共同研究 を実施している。IIASA は日本を含む 18 力国が参加し, 気 候変動などの大規模な変動が社会に及ぼす影響やその持続 可能性などを，環境，経済，技術，社会などの総合的な視 点によって分析することが特徴である。

本稿では，筆者の専門であるエネルギー・環境の視点か ら，ウィーンで感じたことをまとめる。

\section{2. 生活を通して気づくこと}

ヨーロッパ観光では，美麗な教会をはじめとする建築物 や街並み自体が，最高の体験であり醍醐味であることは誰 もが感じるであろう。それとは別に，日本以外に住んでみ ると，その文化，システムの違いに驚く。細かく挙げると きりがないので，ここでは暖房と照明，再生可能エネルギ 一について述べる。

ご存知の通り，ヨーロッパではセントラルヒーティング が主流であり，エアコンの普及率は驚くほど低い。セント ラルヒーティングは，各部屋にヒーターが設置されており， ボイラーから供給される熱水によって部屋が暖められる, というシステムである。基本的には全館一括，24 時間運用 を前提としているシステムであるため，例えばイギリスで は世帯当たりエネルギー消費量の半分以上を暖房によって 消費している（住環境計画研究所による調査結果）。現在住 んでいるアパートは築 100 年を越えているそうで，天井も 非常に高く，セントラルヒーティングだけではエネルギー 消費量は高いだろうし，本当に暖かくなるのだろうか，と 最初は心配したものである。しかし，建物の壁は非常に厚 く, 2 重空であるために, 断熱性能は高いと考えられる。結 果として，この冬に暖房で困ることはなかった。

また，我が家には温度と運転時間を管理するコントロー ラーがあり，昼間と深夜は運転を止めるようセットした。 よって，暖房をほとんど意識することはないため，その工 ネルギー消費量やガス代については無頓着になりがちであ
る。更に，オーストリアの電気/ガス料金は準固定料金であ るため，電気/ガス代についても意識を向けにくい。日本で は『見える化』が省エネルギーにおいても重要との認識が 高まっており，実際に家電製品などに消費電力量が示され る機能などが搭載されつつある。ヨーロッパでの省エネル ギーにおいて，『見える化』を進めることは日本以上に重要 ではないかと感じている。

照明についても，日本との差を明確に感じることができ る。一言でいうと，『暗い』のである。日本では丸型や直管 型の蛍光灯が家庭においても主流であるが，少なくともウ ィーン市内では電球型蛍光灯以外はほとんど見かけない。 我が家では天井に照明器具が設置されておらず（ただし， キッチンとバスルームだけは明るいハロゲンライトが設置 されている), 電球型のフロアランプが頼りである。それも 白熱電球であるため, 当然エネルギー効率は低いので, 切 れるたびに電球型蛍光灯に取り替える。この『暗さ』につ いては，1 ケ月も生活していると慣れてしまったが, 逆に言 うと日本は『明るすぎる』のではないだろうか。この事は IEA のレポート (Light's Labour's Lost) において, データ として示されている。

最後に, オーストリアは水力発電による発電電力量が 50\%を越えていることや, 暖房における木質バイオマス燃料 の比率が他のヨーロッパ諸国に比べて非常に高いことな ど，再生可能エネルギー資源が豊富であることがデータで 示されている。ウィーン市内で生活している限りではその ことを感じることは少ないが，例えばウィーンからブダペ ストへの車空では, 度々風力発電のタービンを目にするこ とができる。しかし，その規模は日本とは桁違いで, 数十 機のタービンがずらっと草原に並んでいる光景は壮観であ る。

\section{3. おわりに}

オーストリア人は，基本的にあまり細かいことは気にし ない。日本人としては, その大らかさや適当さが気になる 場面も多いが，それでも社会は機能するし，受け入れてし まえばそれも心地良い。エネルギー消費行動に関しては, ヨーロッパは日本から学ぶことが多いと考えるが，逆もま た然りである。データだけでなく，体験することによって より深く理解し, 考察することもできる。この貴重な機会 を大切にしたい。

藤澤 星 $[$ 東京電力(株)] (平成 21 年 6 月 22 日受付) 